I started treatment on October 25th, and continued it every ther day until November 4th, but discontinued it on November 6 th, as she had sturted to menstruate. I restarted treatment on November 8th, and continued it every third day till November $23 \mathrm{rd}$, when the ulcer on the les had healed. By November 9th the ulceration on the face had cleared, although there was still some thickness, as well as dilated venules to be seen.

Her general health improved greatly, and she looked better and felt in better spirits than she had done for a long time.

The readiness with which the edges of the ulcer took on healthy appearance was extraordinary, especially as she had ceased to respond to the ordinary methods of syphilitic treatment.

After each injection there was a marked reaction, the face becoming very flushed, and the temperature rising in a short time afterwards as indicated by the two-hourly chart. The four-lourly chart shows it still better.

Her general improvement was a matter of comment by all the others in the ward, and both Dr. Edwards and Dr. Duibar were surprised.

\section{TASE II}

T. A., aged 35, had been in the navy, but after leaving was employed at some works in the neighbourhood, where he received a blow on the arm, as the result of which there was a thickness which persisted longer than the usual bruise. With a history of syphilis, I naturally concluded that this was a syphilitic thickening of the periosteum, and gave him the injections of distilled water every other day. At the end of the fortnight the swelling and pain had disappeared, and he returned to work.

\section{Casf III.}

T. J., aged 46, was admitted to the infirmary on March 6th suffering from multiple ulcers of the left leg ind foot. There suffering from multiple ulcers of the left leg and foot. There Was the brownish scar on the right shin, which confirmed the
diagnosis of syphilis. The ulcers on the left leg and foot would nearly heal and then again break down, but never assumed a healthy appearance. I started injecting distilled water on October 31st, and continued the treatment every other day until November 16th, when I did it every third day. 13y the end of the first week the edges of the ulcers had taken on a very healthy appearance, and the pain from which the man sufferei hat practically disappeared.

There were ten ulcers altogether, and by November 23rd seien of them had healed over, and the two largest were twothirds covered with new tissne. The man appeared healthier, and some colour had returned to his face. He said he felt much better, and looked forward to the time for each injection.

A reference to his temperature chart shows that there was a reaction after each injection, but the temperature did not rise nearly so high as in Case 1 .

\section{Case rv.}

B. T., aged 24, had a hard chancre in. in diameter on the dorsum penis, which appeared a fortnight before I saw him. I started injecting him with distilled water on November 2 nd, and injected him every third day, and by the 14 th it had practically disappeared, as well as the enlargement of the glands in the groin. His general health improved rapidy, and he looked much better after a fortnight's treatment.

Case v.

M. S., aged 20, single, was admitted in November, 1911, as she was pregnant and infected with syphilis. After continement and some treatment she was discharged, to be readmitted on November 11th, 1912, suffering from tertiary ulcers in different parts of the body. There was a small sore on the right ear and one on the right eye, whilst one seemed to be forming on the forehèad.

'Treatment was started on $N$ vember 12 th, and by November 19th there was considerable improvement, the ear and eve being practically well, and the swelling on the forehead had subsided.

All the other ulcers had taken on a healthy appearance, so that by November 25th they were all covered over.

Her general health improved greatly, she see.red brighter, looked healthier, and had colour in her cheeks, whilst the appetite improved. She much appreciated the treatment, al though she cried on the first occasion.

The temperature reactions in this case were very murked, as in Case I, rising a few hours after each injection tó $100^{\circ} \mathrm{F}$.

\section{CASE vi.}

W. E., aged 26, admitted October 10th for sores on the right leg. Was infected with syphilis in the army

Treatment was started on November 10th, and, after injections every third day, the gummats on thigh and leg were all covered over by healthy tissue on November 25 th. A sore inside the right cheek also subsided, whilst his general appearance became more healthy.

The fourth International Congress of School Hygiene will be held at Buffalo, New York, in August next (25th to 30 th), under the honorary presidency of Dr. Woodrow Wilson, President of the United States. The actual president is Dr. Charles W. Eliot, formerly president of Harvard University. The general secretary is Dr. Thomas A. Storey, Professor of Hygiene, College of the City of New York.

\section{The Arris and Gale Pertures}

\section{THE GENITAL FUNCTIONS OF THE DUCTLESS GLANDS IN THE - FEMALE.}

Delivered at the Royal College of Strieons or MaRCh 10TH AND 12Th, 1913,

BY W. BLAIR BELL, B.S., M.D.LoNd., M.IR.C.S.F.ig.,
L.R.C.P.LoNd.,

GFNAFCOLOGICAL SERGFON TO OCT-PATIFNTS, ROYAT. INFIRMARY LIVERPOOL; EXAMINER IN GYNATICOLOGY AND OHSTETKICS TO THE ROYAE COLIFGES OF SCRGIOSS AND PHYSICIANS. LONDON : AND TO THE UNIVERSTY OF DERHAM.

\section{[Abstract. $]$}

LEC'TURE II.

Is the last lecture I endeavoured to estimate the direct and indirect influences of the ovaries in regard to the genital functions. In considering the indirect influences I discussed the effects of ovarian insufficiency, both in physiological and pathological circumstances. on what I may, perhaps, describe as the rest of the genital system of ductless glands; and $I$ also demonstrated the effects prodnced on the general netabolism by this condition.

In this lecture I shall reverse the process and encleavour to trace as far as possible in the time at iny disposal the influence of the rest of the ductless glands upon the ovaries and the reproductive functions generally.

The Relation of the Thyroid to the Genital Systey.

We shall, perhaps, be in a better position to corsider the changes that occur in the rest of the genital system if we first discuss the effect on the general metabolism of removal of this organ.

Effects of Thyroidectomy on the General MLtabolism.

Different mammals vary very much in their power of withstanding the disastrous results which may follow complete removal. I have never observed any grare effects supervene on the removal of the thyroid in rabbits. This has been explained on the ground that the para thyroids are relatively large, and lie well away from the thyroid itself, and consequently cannot be removed with out a careful search-in other words, they escape removal during the operation of thyroidectomy.

Swale Vincent and Jolly have shown that after thyroir. ectomy the parathyroids actually secrete colloid, and, in fact, perform the functions of the thyroid, just as they resemble it in structure after this operation. But I do not believe that this question of the remaining paratliyroids is the whole truth.

I think rodents have less need of the thyroid than other manmals, such as the carnirora. It may be because the diet is different, but also $I$ feel sure it is due in some measure to the variations in the structure and function (or degrees of function) seen in the other ductless glands. I have already alluded to the differences in structure between the ovaries of rodents and the highcr mammals. If we take cats and remove their thyroids many die in a few days, usually with convulsions. In these cases it is probable that the immediate result is due to the removal of the whole thyroid apparatus (thyro-parathyroid). Some, however, survive the operation for a long period of time. In all these cases one can demonstrate the renioval of the whole thyroid together with the internal parathyroids, which are embedded in the two lobes of the thyroid. So that one gets in these animals the true effects of thyroid insufficiency. The number in which the metabolism was investigated fully was small, for, as already stated, many died too soon for tho metabolism, as represented by the urinary excretion, to be estinated. 'The record of one non-pregnaint cat, which was destroyed two and a half months after operation, has been selected as typical. Other cases were complicated by the cats having had kittens shortly before operation, and in consequence did not appear to be suitable for averaging.

In this animal acetone was present three times in twenty estimations after opcration. The calcium excreted 
after operation was the same in quantity as before operation. There was a drop in the phosphorus excretion, in spite of the increase in the post-operation specitic gravity; and the total nitrogen and urea were increased out of proportion to this rise in the specific gravity. The ammonia coefficient also was slightly increased.

Before considering the effect of thyroidectomy on the rest of the ductless glands I will bring forward a rather important series of experiments in which thyroidectomy was performed on three pregnant cats, which survived the operation for some time. They were carried out in order to observe the influence of the thyroid on the metabolism cluring pregnancy, especially wich reference to the possible production of the symptoms of eclampsia with marked alteratious in the ammonia coefficient.

Acetone, albumen, and sugar were found a good many times after operation in one cat, and more frequently after parturition than before, without any real disturbance of the ammonia coefficient.

We found that so long as the cats remained pregnant the calcium excretion remained constant, but that after parturition it was increased to three times the quantity. The phosphates after the birth of kittens showed a remarkable increase, and there was a drop in the urea excreted. There was no real disturbance of the ammonia coefficient.

It does not appear probable, therefore, that the thyroid is in any way specifically connected with the production of eclampsia, as was originally suggested by Nicholson. It is true that two of our cats, which were in the first half of pregnancy, died with convulsions in a few days, but the manner of death was similar in every respect to that seen in non-pregnant animals in similar circumstances.

Effect of Thyroidectomy on the Ovaries and Uterus.

The normal ovary of the cat, with which we are concerned in these experiments, shows certain affinities for eosin in some of its elements. The zona pellucida, the licuor folliculi, the interstitial cells, and the cells of the corpora lutea, all stain faintly with eosin. After thyroidectomy all these elements show an increased avidity for this stain. This is especially true of zona peilucida and the liquor folliculi, and appears to be a matter of some importance.

It seems that removal of the thyroid calls for a response from the ovary, just as oöphorectomy did from the thyroid. Aud the nature of the response, if my observations be correct, is one of considerable interest, for it brings forward evidence that the granulosa cells of the Graatian follicle form an organ of internal secretion. But this secretion is not connected with the integrity of the uterus, for the effect of thyroidectomy on this organ is remarkable. The uterus of the thyroidectomized cat shows very considerable muscular atrophy, quite as much as occur's after oipphorectomy. But the same effect is obtained in the nou-pregnant animal. The importance of this intense atrophy will be considered directly ; for before drawing our final conclusions of these results it will be advisable to consider the clinical observations that have been made in regard to insufficiency of the thyroid.

Clinical Observations of the Effect of Thyroid Insufficiency on the Genital Functions in Women.

These are quite well known. We frequently see young girls with adiposity suffering from anenorrhoea, or we see the more marked insufficiency which produces my xoedenia, and is also invariably associated with suppression of the menstrual function.

Nuw, both the minor and the major state of thyroid insufficiency are readily amenable to thyroid treatment, with one reselvation: if the girl has suffered from thyroid insufficiency for some years past the period of puberty, and has never menstruated, then it may be impossible to relieve her genital condition, and the uterus may remain uncler-developed. If, on the other hand, the insufficiency has arisen later, after the subject has possessed full genital activity, then the uterus may, even after a long period of inactivity, resume its normal functions.

Further, the full and increased activity-if my interpretation of the staining properties be correct-of the secretion of the membrana granu!osa cells, with inactivity of the uterns, puts out of court the hypothesis that the cyclic changes in the uterus are due to this secretion. On the other hand, it is possible that the secretion of the interstitial cells is rendered insufficient in the absence of thyroid secretion.

\section{Effect of Thyroidectomy on the Suprarenals.}

The normal suprarenal structure is well known, but I shall briefly refer to it in order better to illustrate the changes that occur-physiologically and pathologicallyin the cat.

The suprarenal is divided into two parts, the cortex and the medulla. These have different physiological properties when examined experimentally. The medulla produces the well-known pressor effect of adrenin, whilo the cortex is inactire.

Now the changes that seem to indicate excessive activity of the suprarenals occur in the cortex. They may be scen normally in pregnancy and, so far as we know, in ordinary circumstances. The normal appearances differ, however, from those associated with the activity which follows thyroidectomy.

In three of my animals an actual calcareous deposit was found in the zona fasciculata subsequent to thyroidectomy. I have not seen this condition in a normal suprarenal gland.

\section{Effect of Thyroidectomy on the Pituitary.}

The changes that occur seem to be an increase in active eosinophile cells of the pars anterior at the expense of the large basophiles. And both in the pregnant and non-pregnant animal there is an increase of large active chromophobe cells, such as occurs normally in pregnancy. The latter are, of course, most pronounced in an anima! in which thyroidectomy has been performed during pregnancy.

The condition was well seen in Cat $X$ of my series. Forty-eight hours after operation two premature kittens were born. After a further interval of 120 days the animal was destroyed with chloroform. In this length of time all the chromophobe "pregnancy" cells would have disappeared in the ordinary course of events. But as the result of thyroidectomy they not only persisted but showed an increase in secretory activity. The secretion appeared to form vacuoles among the cells. In this case the pars nervosa showed no abnormal invasion of pars intermedia cells.

In the case of a non-pregnant cat (No. 9) killed 79 days after thyroidectomy again many active chromophobe cells were to be seen in the pars anterior, and an increase in active eosinophile cells at the expense of the basophiles.

We learn, then, from these observations that thyroidectomy causes an increase in the secretory activity of all parts of the pituitary body.

The Relation of the Pineal to the Genital System.

The pineal gland has never been successfully removed from mammals; and, owing to its inaccessible position in the brain, there seems to be little likelihood of experimental extirpation ever giving satisfactory results.

The effects of castration on the pineal have already been mentioned.

Clincal Effects of Pineal Disease on the Genital System.

Comparatively few observations have been made, but in most cases where a tumour has been observed it has been a teratema, and somewhat remarkable symptoms have been seen. When the patient was a cliild, as was usually the case, there was a precocious development of the skeletal structures and also of the genital organs. According to $L$. Fidd, who has recently reviewed the literature of the pineal body, all the cases recorded occurred in boys. In a few instances obesity has been seen, but apparently unaccompanied by genital atrophy.

The Relation of the Pituitary to the Genital System. Some of the normal physiological changes in the pituitary which occur are well known. But there is much need for a systematic investigation into the age changes in this organ. So far as I know, only a few isolated observations have been recorded.

There is reason to believe that the secretions of the pituitary determine many of the metabolic functions necessary for the establishment of puberty, or sexual maturity. 
We fully recognize the remarkable enlargement and the histological changes that occur in this gland as the result of pregnancy. The cosinophilia disappears and a large majority of the cells of the pars anterior become chromophobe, and, as already mentioned, have been called "pregnancy" cells.

$\Lambda$ few years ago Dale and also Hick and I showed that an extract of the posterior lobe produces powerful uterine contractions. This effect may be produced physiologically in labour by the infundibular extract.

Ott and Scott first. showed that the same extract is a galactagogue. It is probable that there is an expressor effect. It would be interesting if it were a fact-of which we have no proof-that the pituitary normally promotes the secretion of mills. It is, however, certain, in my opinion, that after the birth of the child the strenm of metabolic products directed to its maintenance and growth in the womb are diverted to the mammary secretion which is to supply its post-natal necessities.

Effects of Removal of the Fituitary (Partial or Complete).

Most of the early work on the extirpation of the pituitary was absolutely unreliable, and it was not until Paulesco improved the technique, which Harvey Cushing and Biedl subsequently adopted, that results worthy of consideration were obtained.

Cushing's conclusions may be summed up as follows: Complete extirpation caused death in a short time. The same effect was obtained by complete extirpation of the pars anterior. Partial removal of the anterior lobe led to the condition known as dystrophia adliposo-genitalis; that is to say, there was great obesity, with atrophy of the genital organs and underurowth in young animals.

Biedl confirmed these findings, and also stated that the posterior lobe (pars intermedia and pars nervosa) wight be removed without producing syniptoms.

It is difficult to believe in the results of experiments in which the anterior or posterior lobe are said to have been removed separately. But there can be no doubt that partial removal of the anterior lobe is not difficult to accomplish; and the results following this procedure should be reliable.

\section{Effects of Removal of the Pars Anteriur.}

On the Ovaries and Uterus.- There is no good description of the histological appearances found, but Cushing states that the Graation follicles disappear while the interstitial cells persist. The uterus also undergoes atrophy. I havo had no opportunity of cxamining ovaries after this operation, but, in view of the genital atrophy, would hare expected the same changes as those which follow thyroid. ectomy - that is to say, the reverse of what has been found by Cushing.

On the Thyroid.-It has been noted by Cushing aud others that there is a remarkable degree of hyperplasia in the thyroid after partial removal of the anterior lobe. This condition eventually subsides, and is superseded, it is said, by a considerable colloid formation, with apparent disappearance of epithelial activity.

On the Thymus.-This leads to lypertroplyy of thic thymus, just as the condition of hypopituitarism is often associated with thymus enlargement.

On the Supravenals.-The operation, according to Cnshing, is followed by hyperplasia and lipoid vacuola tion of the cells of the zona fasciculata.

\section{Clinical Observations of the Effect of Pituitary Insufficiency on the Genital Functions in Women.}

These have been made chiefly in regard to acromegaly and the condition already described as dystrophia adiposogenitalis. The former cisease is supposed to be due to excess of secretion, and the latter to deficiency.

The relationship of these two contitions, howerer, is not quite so simple as the above statement would seem to inply. It is usual to find amenorrhoea both with acromegaly and with the condition which is supposel to represent the opposite in regard to secretory activity.

With acromegaly the excessive thickening of bones indicates calcium retention-a condition which appears associated with masculinity, as we shall see when dealing with the suprarenals.

In cases of dystrophia adiposo-genitalis genital atrophy is invariable, yet there is no doubt that, if the individual has had functional activity before the onset of the discase, this activity may retu'n on relief of the condition by decompression or by administration of pituitary extract. I have obserred this result follow injections of anterior lobe extract in dystrophia adiposo-genitalis. Similarly I have seen good results after the administration of this preparation in cases in which the paticnt was rery obesc and suffered from amenorrhoca, without showing the signs of intracranial pressure which are usual when the condition has reached the stage of dystrophia adiposo. genitalis.

Success is morc likely when the patient has had some functional activity previously; but it is possible that delayed menstruation with obesity might be successfully treated if the patient has not long passed the usual age of puberty.

\section{The Rifation of the Thries Glaxd to the Genttal} Systris.

The thymus has been shown to have a rery important relation to the derelopment of the individual and of her reproductive functions. It is probable that once the genital functions are established the thymus rapiclly undergocs atrophy, and plays no further part in the metabolism of reproduction. We have already seen that the thymus undergoes hyperplasia after removal of the ovaries.

\section{Jiffects of Thymectomy on the Oraries and on the} Calcium Melulolism.

Paton found that if the operation be performed before puberty there is a rapid development of the genital glands. It appears, therefore. as if the thymus either inhibits the derelopment of the ovaries (IBiedl), or that their development follows the withdiawal of the thymus secretion.

It is highly probable that the thymus is intimately connected with the calcium netabolism; but it can hardly be, as Bierll suggests, that the effect of its secretion is to cause calcium retention in the bones-althongh severa investigators (Basch. Cozzolino, Tarnlli, and Lo Monaco) have found that rickets follows thymectomy in young animals, an effect not confirmed by Paton-for the skeletal structures become much more heavily larken with calcium phosphate after puberty when the gland atrophies.

Effects of Thymectomy on the Other Inctless Giands.

No reliable work appears to hare been done on these lines. It is urgently needed, in order to clear up many of the difficulties concerning the relation of the thymus to the general metabolism.

\section{The Relation of tile Scpiafreals to the Genital} Srstem.

These glands may be studied in the same way that we have already adopted-that is, from a plyssiological and pathological standpoint.

In pregnancy certain changes occur normally in the suprarenals. So far as my own observations go these are confined to the cortex. The cells of the zona fasciculata appear swollen and cloudy.

Some observers (Ginicysse and Gottschan) have found that in pregnancy the zona fasciculata increases in thick. ness at the expense of the zona reticularis and medulla. My own observations are in accord with this.

\section{Eifects of Remoral of the Suprarenals.}

In most mammals complete removal of the suprarenals causes dea'h in from a few hours to a few days.

Many rats, owing to the fact that a large percentage of them have accessory iuterrenals, consisting of cortical substance, are said to be able to survive extirpation of the main organs. I have had no experience of extirpation experiments on these animals. My investigations have been carried out on rabbits and cats. 'Those from which both suprarenals were remored, cither at one or at two sittings, died within forty cight hours. I tried, therefore, the effect of the removal of one suprarenal in the hope of being able to produce insufficiency, since we know the other suprarenal hypertrophies in these circumstances, and shows a condition somewhat comparable with the hyperplasia of preguancy. Tro cats gare negative results in 
regard to the metabolinm; but with regart to two rabbits I obtained definite results: Ono of tho animals was destroyed at tho end of thirty days, as it we s obviously dying. It was nuch emaciated, its weight having drupped from 2,000 to 1,400 grenus.

'Tho other rabbit died at the end of 127 days. It also was greatly emaciated, its weight having decieased frou 1,710 to 1,020 grams. At fir'st it gained weight after tho operation, and then it steadily lost ground.

No cause for deatl was fonnd in either casc.

'These results are apparently of some value, for, according to most recent authorities, unilateral extirpation in rabbits produces no symptomis.

With regard to the metaboiism, we obtained very interesting results. In each case a considerable increase in the excretion of calcium was observerl.

In one case the averige quantity excreted after operation was seven times as much as that cxcreted beforc operation. In the other case it was sixteen times as much. Tho average for the two cases was, of comse, between these figures. The excretion of phospliosus was not increased in proportion, as one might liave expected.

The urea excretion was increased ont of proportion to the differences between the specitic gravitics bafore and after operation.

Now this increase of the calcium excretion is of rery considerable interest. It is well known that the view has been advanced that osteomalacia is due to insufficicucy of suprarenal secretion, and Bossi first called attention to the beneficial results to be obtained by the injection of adrenin in these cases. Unfortunately I liave not met with a case of osteomalacil in recent years. So I havo liad no experience of this treatment. But these experiments give very strong support to this view of Bossi, not only in the netabolisin results, but in a most striling way in regard to the bones of onc of these animals.

The bones of the forelegs-on which I presume a good deal of weight would fall-were found to be markedly bent. The bones of the backlegs, which are thicker, wero only slightly curved. But owing to the manner in which a rabbit sits rery little weight would fall on these bones.

\section{Effects of Suprarenal Removal upon the Piluitury Budy.}

Tho changes that occur secm to be much the same whether the insufficiency be acute or chronic; thus in cat No. 1 of my series of suprarenal removals, the glands from both sides were removed at the same time. Fliere was an interval of thirty-six hour's between operation and deatl.

The cells of the pars anterior show a marked degree of cluromophobia witl a moderate degree of faint cosinophilia. In many places the nuclei are very deeply stained with hacmatox ylin.

In the pars internediat the cells are liscrete-tluat is to say, they are not fuserl, and show no special activity; the nuclei stand out prominentiy.

The pars nelvosa is freely invarled by the cells of the pars intermedia, but the nuclei only are prominent, as though they were left stranded after the disapi) callance of the cell eytuplasin.

We camot, therefore, come to any conclusion other than that the anterior lobe shows increased activity. 'The par's intermedia is cortainly not in an actively secreting condi tion, but the citcusive invasion of tle pilis nervosia by pars intermedia celis, and the rapid disapucarance of the edl cytoplasu!, appear to indicate tlat an attempt is being narle to counterbalance the loss of adrenin by the rapid production of infunclibulin.

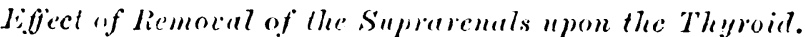

I lave been unable to trace any histological change cither in acute or chronic supratrenal insutticiency.

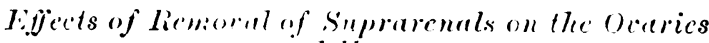

$$
\begin{aligned}
& \text { iinl lererles. }
\end{aligned}
$$

There appears to bo no histological change of importance in the oraty: but it is workhy of note that the normal cosimplatia of the zoma pellucilat is not decreased-ratlere, if anything, is it increased. After removal of one sumrarenal, if insufliciency be prolured, the uterus appears to undergo changes compariable with those that are secn after thyroidectomy, but the muscular atrophy appears to bo less in extent; probably this is due to tho state of incomplete insufficiency.

\section{Clinical Observations of the Effect of Pathological Lesions} of the Suprarcuals on the Genital System.

We meet with conditions in the human subject which epresent both an under-secretion and an over-secretion of the suprarenals. This is decided on clinical and histo. logical evilence. At the same time, we are still in the dark as to the exact relationship of the cortex to the medulla.

In Addison's disease we have what aro apparently the symptoms of insufliciency of medullary secretion, as is shown by the low blood pressure and general muscular weakness. But in this disease the cortex also is destroyed.

It is doubtful if sufficient pathological observations have been mate with a view of observing changes in the ovary and uterus to cnablo us to gire any definite statements regarding them.

Amcnorthoca is, I believe, usually associated with Adelison's disease, but this may be due solely to the effect. of a comlition which prorluces gencral progressive enfeeblement. On the other hand, our experimental evidence indicates that atrophy of the uterus, and presumably insufticiency of the function of the interstitial cells, occur's in these circumstances.

'The other pathological lesions which have been subjected to a good deal of attention lately are hyperplasia and tumour formation in the suprarenal cortex. For some years these lesions have been known to be associated with extraordinary changes in the primary ancl secondary sex characteristics. Attention was first called to these interesting phenomena by Woolley, Bulloch and Sequeira, and Neugebaner.

Last year my colleague, Professor Ernest Glynn, reviewer cxhaustively the whole subject and added 5 fresh cases in children to those already collected by Bulloch. Out of 17 cases in children 14 were females. In these there was usually skeletal overgrowth, hair on the face and pubes, and sometimes hypertroplyy of the clitoris. Further; Gilynn collected 6 cases occurring in young aciult females, in all of whom there was growth of hair on the face, shrinliage of the breasts, amenorrhoea, and sometimes a masculine voicc.

Pathologically the suprarenal enlargement in the children and young adult females was unilateral and neoplastic in character, and directly or indirectly caused deatl. Neta. stases were sometimes found.

In a second group of cases there were 13 pseudohermaphrodites-12 being females-aud in these the suprarenal eulargement was bilateral, hyperplasic in character, and there were no metastases.

Glymm suggested that in these cases lyperplasia of the suprarenal cortex occurred in fetal life before the differ. entiation of the genital ducts, and led to the persistence of the Wolftian derivatives, thus causing female pseurlohermaphroditism.

No sex changes are associated with tumours of tho smprarenal cortex when they occur in adult males or in women after the monopause.

The Correlation of the INteriat Secherioss in regind To Their Genital Fuxctons.

I have endeavoured to trace, for the most part from my own observations, the disjointer facts concerning the influences exerted by the different members of the ductless gland system upon one another and on the metabolism generally, in so far as the genital system is concerned. And in so doing I have sometimes shown clearly the nature of the associations between the different orgaus But it is absolutely impossible at the present time to correlate fully all their functions, so that perhaps the less said now the less there will be to withdraw at some future date.

In view, howerer, of what I said at the commencement as to the necessity for a lead in this intricate matter, I cannot refrain from enumciating what $I$ believe to be the general principles. I shall not have timo iurther to analyze the details.

It appears, from the evidence at our disposal, that, in spite of great variations in the structure of the ductless 
glands in different mammals, the total functional result is the same so far as the genital processes are concerned. The rariations in function that depend on the differences of structure are probably related to differences in the food and habits of life.

In adapting our knowledge to the requirements of human physiology and pathology we must take into account both the essential functions I have already referred to-the individual metabolism of the mother and the metabolism of her reproductive functions-for they are completely interdependent.

We have seen as the result of our studies that the ovaries, on the one hand, have as their share of these dual functions the onus of crs aring the reproduction of the species, by furnishing the ova and by keeping active the rest of the genital structures and functions. And, further, the secretions of the ovary are concerned in kecping the other members of the ductless gland system in tonch with the necessities of the reproductive situation. The latter function is of the decpest importance, and is one which explains much that would otherwise be obscure.

When the reprodnctive functions cease and the ovaries atrophy at the menopause the harmony that previonsly existed between the general and the genital metabolism is temporarily deranged, and varions disturbances may ensue. And it is only by the careful investigation of each menonausal case that one can arrive at a detcrmination of the manner in which the balance has becn upset. It is impossible always to alleviate the symptoms, but the basis of treatiment rests on the regulation of the existing disarrangement by the achministration of the necessary secretions. Some patients react to thyroid extract, some to pituitary, others again to combinations, so great are the individual variations. In most cases a natural readjustment takes place in the course of time. So that, strietly speaking, the ovary is only concerued in the temporary function of reproducing the species, and, by its hor'uones or intermal secretions, of bending the metabolism of the body to its purpose. As accessory to these functions the ovary has becn supposed to be responsible for the beauty of the vessel by means of which its encls are to be attained. But to-day we are beginning to wonder how fir the ovary does influence secondary sex characteristics, and whetlier full individual secondary characteristies can be obtained by the influence of the ovary alone.

We have evidence that hyperplasia of the suprarenal cortex can upset any influence the female genital gland mily be supposed to possess, and can produce in a female some of the secondary characteristics of the male, and even partially cliange the genitalia to complete the picture.

I well remember sccing a case uncler the eare of $\mathrm{Dr}$. linssell Andrews. 'The subject possessed every female wharacteristic except for the absence of nterus, Fallopian tubes, and ovaries; insteacl there were testes within the ablominal cavity. 'This individual was a male piscudohermephodite with the pure secondary characteristics of a female, and a prepossessing one at that. Such a condition could not have existed with hyperplasia of the suprarcnal cortex.

Any influence the orary has over the general metabolis!n is, then, related to and dependent on its primary reproductive function. I do not believe that it influences the metabolism excent in so far as this special function is concernct. Of course, remuval of the ovaries may produce a temporary disturbence, but this has alrearly been explained, and does not invalidate the view just mentioned.

On the other hand, the rest of the ductless gland system is related to the genital function in varions ways.

First, some of the members - the thyroid, pituitary, and suprarenals-influence the derclopment and subsequently preserve the integrity and activity of the genitalia. ats i have already demonstiated. Others--the thymus ancl possibly the pineal-appear to prevent sexual precocity.

secondly, all the ductless glauds control the metabolism in response to the necessitics of the genital functions; but, in addition, they adapt the whole organism to the possi. bility of the situation and regulate the secondary characteristics, both physical and psychical, to suit the needs of the individual. Once, however, the reproductive organs are removed or undergo atrophy, the primary genital functions of the rest of the ductless glands cease, and tho rearrangement of the metabolism that follows proluces what are known as the symptoms of the menopausc. Contrariwise insufficiency of the thyroid, pituitary. or suprarenals causes the cessation of the genital functions with atrophy of the uterus.

As to the more particular parts played in the metabolism by each member of the ductles's gland system, these havo already been specified.

In spite, therefore, of the reluctance to correlate our knowledge shown by most investigator's, the matter is not one of very great complexity if my views be correct in a gencral way, although there remains much detail to fill in.

As soon as possible we must come to a conclusion ats to what are the fact:s. So much work that has been donc is contradictory. There is therefore so much more the need for further efforts.

In concluding, I would again insist that in order to solve completely the problems surrounding the genital functions we must focus at one and the same time the two essential processes of life-the individual metabolism and the reproductive metabolism. They are absolutely interdependent. Indeed, tho iudividual metabolism is the reproductivo metabolism. It is the neglect of this point of view that lias brought about much of the confusion that cxists.

Weismann and hay Laukester describe the relation between the reproductive cells and those of the soma in still more striking terms. The latter says: "Among the multicellular animals, cortatin cells are separated from the rest of the constituent mits of the body, as egr cells and sperm cells: these conjugate and continue to live, whilst the remaining cells, the mere carriers as it were of the immortal reproductive cells. die and disintegrate. 'The borlies of the higher animals which die may from this point of view be reginded as something temporary and non. essential, destined merely to carry for a time, to nurse and to nouris! the more important and deathless fissicu products of the unicellular egg."

Whaterer views we may hold as to cletails, I question whether this philosophical statemert is open to contradiction.

The function of reprofluction in all its preparations and perfurmances commences in the early stages of segmentation. and may be said to continue in man until the care of the off spring is completerl.

In many insects, male and female, the act of repro. duction is also the cause of death. Evolution and tho pressing necessities of individual life have led men to look upon the function of reproduction as of vastly inferior importance to their own individual metabolism. No duubt women will soon come to think so too, for they seen: to be chimsing. Whether this change be due to an increasing hyperplisia of the female suprateual cortex $I$ do not linow. Bint just as we are begimniug to think that our limowherese of their special functions is becoming well defined they invite us to follow their further crolution, which aplaiently they think will not involve them in the jors of motherhood.

fimont said "l'ropter solum ulermm mulier est gued est"; Chrvau changed this to "Propter getrium solum mulier est culuol est.

Virchow reiterated this statement and, according to Biedl, adterl that '. Ill the peculiarities of her body and mind. . . everything. in fact. which in the true woman we admire and revere a:s womanly, is dependent on tho ovary."

In the light of our prescnt knowled ge I venture to think that the following aphorism more nearly deseribes the cause and effect:

Propter secretiones interind; toles mulice est quorl est.

The original work detailed in thess jectures, which were illustrated with many plotomiceographs and colour photomicrographs. Was carricel ont in the Biochentical and Pathological Laboratories in the lnirersity of Li:erpool; and I am much inrlebted to Professor Benjanin Mloore and Professor Ernest (ilynn for help in varions directions, and especially for the facilitic's accorded to my assistants, and for the siperintendence of their work.

The entire expenses were defrayed out of the J. Arthur Smith Rescarch Funil. 